50. Serbyn, R. (2008). The Ukrainian Famine of 1932-1933 and the United Nations Convention on Genocide // Famine in Ukraine 1932-1933: Genocide by Other Means. Ed. Taras Hunczak and Roman Serbyn. New York: Shevchenko Scientific Society, 2007. Mode of access: http:/ www.holodomorsurvivors.ca/Roman\%20Serbyn.html

\section{Л. Дубінка-Гуща}

\section{ПОЛІТИКА КОЛЕКТИВНОЇ ПАМ'ЯТІ: ОГЛЯД ІСТОРІОГРАФІЇ ПІВНІЧНОЄВРОПЕЙСЬКИХ КРАЇН ЩОДО УКРАЇНСЬКОГО ГОЛОДУ 1932-33 POKIB}

Постановка проблеми. Окрім теоретичних підходів до міждисциплінарних досліджень політики пам'яті у постглобалізованому світі, важливо дослідити присутність українського голоду в північноєвропейській історіографії, вказуючи на існуючий пробіл в академічних дослідженнях на цю тему у північноєвропейських країнах.

Мета статті - 3'ясувати як теоретичну, так i емпіричну основу для подальшого аналізу північноєвропейської історіографії радянського голоду 1930 -х років.

Основні результати дослідження. Автором розкрито, що політична пам'ять має не лише широкі та складні теоретичні наслідки, переходячи до декількох дисциплін, але й імперативні практики, які можуть діяти як герої чи лиходії в боротьбі за національну ідентичність. Обговорено роль міжнародного визнання Голодомору як геноциду для України та українців, що призвело до висновку, що він має вирішальне значення насамперед для історичного наративу та історичної пам' яті, що сильно впливає на сучасне самосприйняття пострадянських країн. Створена концепція геноцидації може стати новим підходом до аналізу постбіполярної та постглобалізаційної політики ідентичності.

У Данії та Швеції знання про «український Голокост» обмежені кількома публікаціями північноєвропейських вчених та перекладеними творами видатних міжнародних учених. Це відображає загальний обережний підхід у скандинавських країнах до потенційно чутливих питань, пов'язаних із Радянським Союзом. Тому значний потенціал $\epsilon$ i в майбутніх дослідженнях північноєвропейських дипломатичних архівів та 3MI, що висвітлюють ситуацію в РадянськомуСоюзі в 1930х роках.

Висновки. Підводячи підсумок, ця стаття є спробою відкрити напрям порівняльних досліджень у північноєвропейській історіографії радянських голодоморів, взявши за відправну точку дискурс про ідентичність як частину процесу націотворення (lieux de mйmoire). Однак майбутнє Європи, безсумнівно, залежить від здатності подолати вузькі національні дискурси lieux de mйтоire як технічного політичного інструментарію та здобути мудрість взаєморозуміння та прощення.

Ключові слова: колективна пам'ять, геноцидація, Голодомор, Україна, геноцид, радянський голод, північноєвропейська історіографія.
УДК930(477)”195-199":[330.142.21:63-048.87"192"](045) DOI: 10.31651/2413-8142-2019-21-88-97

Ю. М. Лазуренко

кандидат історичних наук, доиент кафедри історії та права Черкаського державного технологічного

університету

\section{РОЗВИТОК ПРОДУКТИВНИХ СИЛ У СІЛЬСЬКОМУ ГОСПОДАРСТВІ УКРАЇНИ ДОБИ НЕПУ В КОНТЕКСТІДІЯЛЬНОСТІ СІЛЬСЬКОГОСПОДАРСЬКОЇ КООПЕРАЦІї: ІСТОРІОГРАФІЯ КІНЦЯ 50-Х - ПОЧАТКУ 90-X PP. XX CT.}

У статті висвітлено розвиток продуктивних сил у сільському господарстві Украӥни в контексті діяльності сільськогосподарськоӥ кооперачї періоду нової економічної політики у вітчизняній історіографії кіния 1950-х - початку 1990-х рр. Доведено, шо радянські дослідники, на відміну від зарубіжних науковців, загалом мало уваги звертали на кооперацію в украӥнському селі як на цілісний господарський та соціальний організм, висуваючи на перчий план лище так звані виробничі форми коопераиіï. Констатовано, щуо в історіографії 1920-x - початку 1950-x рр. проблема сільськогосподарської кооперачї взагалі замовчувалась. Лише з другої половини 1950-х рр., особливо після ряду публікаиій вченого-аграрника В. Данилова, інтерес науковців до сільськогосподарської кооперачї пожвавився. Проте кардинально ситуація змінилася лише за часів «перебудови».

Ключові слова: історіографія, неп, селянство, селянські господарства, сільське господарство, сільськогосподарська кооперація.

Постановка проблеми. Подальший розвиток України як сучасної, соціальноорієнтованої європейської держави потребує модернізації аграрного сектору економіки. Його успішне реформування не можливе без урахування попереднього історичного досвіду. Більшість як вітчизняних, так і зарубіжних дослідників сходяться на тому, що виробничо-економічний, а отже і соціальний розвиток українського села $1920-x$ рр. носив прогресивний характер, а період нової економічної політики мав багато спільних рис із сучасною економічною моделлю. У зв'язку з цим спеціальний аналіз вітчизняного історичного досвіду функціонування сільського господарства України в добу непу $є$ цілком доцільним, тим більше, що увага українського суспільства щодо подальших шляхів налагодженням ефективного функціонування аграрного сектору народного господарства залишається гранично високою.

Історіографічне узагальнення, здатне покращити якість подальших аграрних студій, зумовлене значним нагромадженням історичних знань про розвиток сільськогосподарської кооперації в роки непу. Науковий інтерес до порушеної нами теми визначається необхідністю виокремлення різних концептуальних підходів, що сприятимуть акумулюванню і подальшому розвитку історичних знань із різних аспектів розвитку продуктивних сил в українському селі в роки непу.

Аналіз останніх досліджень і публікацій. До розкриття обраної нами для вивчення теми зверталися 
такі сучасні дослідники, як С. Кульчицький, В. Марочко, А. Морозов, Т. Оніпко, С. Биченко, В. Лазуренко, І. Кивгила, Ю. Тренкін [1].

Автор статті ставить за мету вивчити розвиток продуктивних сил в сільському господарстві України в контексті діяльності сільськогосподарської кооперації періоду нової економічної політики у історіографії кінця 50-х - початку 90-х рр. ХХ ст.

Виклад основного матеріалу. Об'єктивне вивчення діяльності української сільськогосподарської кооперації доби непу, припинившись на зламі 1920-х - 1930-х рр., за незначним винятком «відлиги», до середини 1980-х рр. фактично не велось. Більшість праць цього історіографічного періоду були написані без розуміння самодіяльної природи кооперації як об'єднання дрібних товаровиробників. Натомість провідною стала тема «сільгоспкооперації як шляху до колективізації».

Методологічною основою досліджень в цій царині був так званий «кооперативний план» В. Леніна, який на довгі десятиліття став своєрідним дороговказом для радянських дослідників історії селянства доби непу. Суть цього плану була викладена і в «Короткому курсі історії ВКП(б)». Фактично мова йшла про свідому фальсифікацію поглядів В. Леніна на роль кооперації, викладену ним у праці, що стала вершиною його теоретичного осмислення природи кооперації. Намагаючись надати хоч якоїсь привабливості ідеї насильницької колективізації, яка, за своїм змістом була схожою на звичайну реквізицію, Й. Сталін та його оточення цілком свідомо вирішили використати господарський авторитет та усталену громадську довіру до селянства, до кооперації, власне навіть саму iii назву як суто декоративний елемент, який мав маскувати зовсім іншу господарсько-виробничу, громадську та юридичну структуру.

Погляди В. Леніна на роль сільгоспкооперації трактувалися суто в плані переходу індивідуальних селянських господарств до так званих вищих форм кооперації, тобто мова йшла про необхідність утвердження колективних форм господарювання. Партійні теоретики виводили їх безпосередньо 3 готовності сільського господарства до «великого перелому». Так, ще наприкінці 1929 р. М. Владімирський, відомий радянський партійний i державний діяч, один із «батьків» червінця, писав, що «кооперація починає розвиватись в нових, більш високих формах, які є обумовленими новим, більш високим рівнем розвитку продуктивних сил» $[2,8]$.

Починаючи 3 другої половини 1930-х рp., у періодиці дедалі частіше стверджувалося, що кооперативний план $є$ своєрідним синтезом ідей В. Леніна і Й. Сталіна: «Ленінсько-сталінський кооперативний план, вчення про колективізацію трудових селянських господарств надав партії можливість знайти правильний шлях залучення села в русло соціалізму» $[3,4]$. Підкреслювалося, що саме Й. Сталін і став безпосереднім втілювачем у життя «великих ідей Леніна».

Об'єктивне вивчення сільськогосподарської кооперації взагалі припинилося. Сталінська парадигма радянської історії, викладена в «Короткому курсі історії ВКП(б)», стала домінуючою у вивченні кооперації радянськими науковцями, які більшою мірою актуалізували досягнення соціалістичного будівництва тільки в контексті діяльності колгоспів.
Відповідно багатогранна діяльність сільськогосподарської кооперації 1920-х рр. зовсім не вивчалася.

Лише у другій половині 1950-х рр. у ряді досліджень знайшли відображення матеріали, в яких проаналізовано питання історії кооперації в радянському селі на початковому етапі непу [4]. Щоправда, такі автори, як Б. Абрамов, М. Смірнов все ще в дусі попередньої доби відзначали, що основною причиною труднощів у сільському господарстві в роки непу була господарсько-економічна діяльність заможних селянських господарств. Дослідники применшували значення кооперації у справі піднесення сільськогосподарського виробництва [5]. Загалом удругій половині 1950-х рр., як і в попередні десятиліття функціонування радянського колгоспного ладу, в історіографії продовжувала домінувати думка про те, що найвищою формою кооперації, а відтак кінцевою метою їі розвитку є колективні господарства [6].

У 1955 р. у Німеччині побачила світ праця відомого російського економіста-емігранта А. Билимовича «Кооперація в Росії до, під час і після більшовиків» [7]. Тривалий час ця робота була невідома широкому загалу науковців. Монографія була перевидана Інститутом економіки РАН лише у 2005 р. [8]. Дослідник обстоював тезу щодо того, що радянський лад не має достатніх історичних перспектив. Ще у 1960 р. він закінчив роботу «Економіка звільненої Росії», в якій детально виклав свої міркування стосовно розвитку «післябільшовицької Росії». Характерно, однак, що відносно періоду непу він висловився оптимістично, спеціально зазначивши, що після прогнозованої ним втрати влади Комуністичною партією для радянської країни найбільш придатним господарським механізмом буде економіка змішаного типу. До головних причин деградації продуктивних сил у сільському господарстві та згортання непу наприкінці 1920-х рр. він зарахував наперед сплановану із суто політичних міркувань так звану «тотальну примусову колективізацію сільського господарства, при якій селянство і сільськогосподарське виробництво були принесені в жертву ідеологічним і економічним цілям радянської влади» [9].

У другій половині у 1950-х - у першій половині 1960-х рр. українські дослідники загалом відновили студіювання кооперативної проблематики, але вони не виходили за межі партійної парадигми [10]. Практично всі опубліковані дослідження, в яких порушено проблему сільськогосподарської кооперації, у вигляді обов'язкового «довіску» мали специфічне навантаження - показати, що досягненні нею успіхи завдячувались увазі партії.

Так, зокрема М. Гетьман-Кравченко, досліджуючи розвиток сільськогосподарської кооперації доби непу, ключове значення надавав керівній ролі Комуністичної партії у цьому процесі [11]. Такі ж акценти були характерні для дисертації П. Бакуменка [12]. Так, другий розділ праці науковець спеціально присвятив висвітленню економічної співпраці робітничого класу і селянства. Разом із тим, окрім аналізу земельної, податкової й кредитної політики радянської влади на селі, дослідник показав також суспільне та економічне значення сільськогосподарської кооперації. Він спеціально підкреслив, що наприкінці відбудовчого періоду 
сільськогосподарська кооперація являла собою «найбільш поширену на Україні і перетворилась у велику господарську організацію, мережа якої охоплювала 1,6 млн. дворів, тобто більше 30 \% усіх селянських господарств» [13].

У дисертації I. Слинька «Перемога колгоспного ладу на Україні (1927 - 1932 рр.)» показано провідну роль сільськогосподарської кооперації в матеріальнотехнічному забезпеченні села. Так, він спеціально підкреслив, що сільгоспкооперація відіграла вирішальну роль у забезпеченні селянських господарств складною машинною технікою, в організації прокатних пунктів, будівництві підприємств iз переробки сільськогосподарської сировини допомагала підвищувати культуру землеробства $[13$, 30].

Важливі економічні аспекти господарської діяльності кооперації на селі розкрито у монографії 3. Шульги [14].

Плідно продовжував працювати в цьому напрямі вчений-аграрник В. Данилов. Так, на його переконання, сільськогосподарське кооперування «дало можливості трудящому селянину підняти рівень забезпечення його господарства засобами виробництва, розширити посівні площі, збільшити доходи» [15]. Науковець також підкреслив, що кооперація на селі активно кредитувала селянські господарства та збуто-постачальницьку діяльність, замінюючи «скупника і приватного торговця, відповідно до цього сфера буржуазних відносин в збутовому обігу села зменшувалась» [16].

Розвиток продуктивних сил села в контексті роботи сільськогосподарської кооперації на початку 1920-х pp. доволі широко розкрито і в дисертаціях І. Громенко, М. Терещенко [17].

Предметом інтенсивних досліджень у 1960-ті pp. став також ленінський кооперативний план [18]. 3'ясуванню суті й значення кооперації в сільськогосподарському механізмі 1920-х рр. було відведено значне місце в роботах Г. Бланк, І. Булатова, В. Голікова, А. Коссого [19]. Так, В. Голіков наголошував, що важливою проблемою розвитку сільськогосподарської кооперації було недостатнє кредитування останньої з боку держави [20]. Навіть створення Центрального сільськогосподарського банку СРСР не вирішило цієї проблеми. Сільськогосподарська кооперація, попри всі свої успіхи, залишалася «слабкою в матеріальному і організаційному відношенні» [20, 73]. Та, незважаючи на це, на переконання В. Голікова, «кооперація, особливо сільськогосподарська, була головним засобом підйому продуктивних сил села, покращення положення селян, розгортання товарообігу в країні і зростання на цій основі внутрішнього ринку» $[20,138]$.

Проблемам життя сільськогосподарської кооперації України 1920-х років приділив належну увагу і відомий канадський історик I. Витанович. Один із розділів своєї монографії «Історія українського кооперативного руху» він присвятив показу руйнування кооперації за часів «воєнного комунізму» та їі відбудови в роки непу. Автор акцентував увагу на недоцільності втручання правлячої партії у кооперативне будівництво, підкреслив економічне значення відродження кооперації, іiі значну роль у відбудовчих процесах на селі [21].
3 другої половини 1960-х рр. вивченням кооперативної проблематики загалом i сільськогосподарської кооперації років нової економічної політики зокрема, інтенсивно займалися I. Громенко [22], Л. Морозов [23], Л. Файн, П. Денисовець [24]. Заслуга згаданих науковців полягає вже в тому, що вони показали особливості кооперативної політики радянської влади та її значення в контексті піднесення сільськогосподарського виробництва. Л. Морозов, зокрема, акцентував увагу на ролі сільськогосподарської кооперації в господарському механізмі, ступені впливу радянської влади на процеси кооперування. Науковець прослідкував трансформацію поглядів на кооперацію як форму держкапіталізму всередині правлячої партії на початку непу та поступовий перегляд цієї позиції під час безпосереднього здійснення нової економічної політики після оприлюднення концептуальної статті В. Леніна «Про кооперацію».

Інший активний дослідник кооперативної тематики В. Дмитренко звернув увагу на постачальницьку закупівельно-посередницьку діяльність кооперації. Він показав, що кооперація виконувала роль основного поєднуючого елементу між промисловістю і сільським господарством та сприяла підйому продуктивних сил останнього. Водночас важливим результатом кооперативного будівництва на селі, на думку автора, було переведення «дрібнотоварного виробництва на рейки соціалістичного розвитку» $[25,130]$. Тобто, кооперативна торгівля, на переконання автора, стала тим фактором, який вплинув на витіснення приватника і змінення союзу робочого класу 3 селянством, що дало результати у піднесенні виробництва.

На початку 1970-х pp. А. Чмига, значно розширивши джерельну базу попередніх досліджень, створила фундаментальну працю 3 історії колгоспного будівництва в Україні, яка хронологічно охоплювала 1917 - 1929 рр. У ній було розкрито ряд цікавих регіональних особливостей розвитку колективних господарств, показано механізм господарської взаємодії кооперації й колгоспів [26]. Із загальним спрямуванням дослідження А. Чмиги співзвучна і монографія І. Зеленіна «Радгоспи в перше десятиліття Радянської влади (1917 - 1927 рр.)» [27]. У iї п’ятому розділі дослідник, аналізуючи виробничу і агрокультурну діяльність радгоспів, показав і те, як через сільгоспкооперацію вони взаємодіяли із селянським одноосібним господарствам.

Цікава інформація про діяльність сільськогосподарської кооперації України доби непу міститься в третьому томі «Історії соціалістичної економіки СРСР» [28]. Так, Е. Каплінський відзначив, що найбільшого розвитку сільгоспкооперація досягла в районах діяльності спеціалізованої сільськогосподарської кооперації, яка в другій половині 1920-х років найбільш інтенсивно розвивалася в Україні. На підтвердження своїх висновків автор для прикладу навів такі дані: «На 1 жовтня 1926 р. при середній кооперованості селянських господарств в країні близько 30 \% в основних молочно-тваринницьких районах кооперація охопила 40 - $97 \%$ господарств, в районах діяльності господарств тютюнової і бурякосійної - 80 \%, насіннєвої - 50-80 \%» [28, 339]. Аналізуючи рівень сприйняття селянами різних 
регіонів України ідеї колективізації, він зосередив увагу на значній ролі контрактації в цьому контексті. Важливим підсумком діяльності сільгоспкооперації дослідник назвав її активну участь у господарському розвитку села та розширенні мережі сільськогосподарської кооперації протягом 1920-х pp. шляхом організації вигідної для селянських господарств виробничої контрактації. Нагадаємо, що виробнича контрактація включала в себе низкузаходів фінансово-економічного (кредитування), організаційного, агрокультурного, збутопостачальницького характеру. Завдяки цьому напередодні масової колективізації сільськогосподарська кооперація України об'єднувала 55 \% селянських господарств [28, 340].

Важливим етапом дослідження діяльності сільськогосподарської кооперації доби непу стала колективна монографія «Партія і кооперація» В. Дмитренка, Л. Морозова, В. Погудіна [29]. Автори проаналізували партійно-господарські рішення 1920-х pp. у сфері кооперативного будівництва. Вони дійшли висновку, що з упровадженням нової економічної політики, «сфера господарської діяльності кооперації розширилась за рахунок заготівлі продуктів харчування для населення і сировини для промисловості, організації товарообігу між містом і селом, безпосереднього торгового зв'язку між дрібним товаровиробником i державною промисловістю» [29, 134]. Досить чітко простежено й еволюцію поглядів на кооперацію представниками партійного середовища. Автори ще раз відзначили важливе значення статті В. Леніна «Про кооперацію», після публікації якої сталися суттєві зміни державної політики в кооперативній сфері. Дослідники спеціально відзначили той факт, що роль сільгоспкооперації залишалася вирішальною і в реконструктивний період, коли головним завданням стало форсування колективізації.

На особливу увагу заслуговує концепція розвитку кооперації, сформульована В. Даниловим [30]. «Вигідність кооперативної торгівлі, - відзначав науковець, - послугувала основою швидкого зростання споживчої кооперації в селі» [31, 209]. Відповідно найбільш масовою на селі на початку непу була споживча кооперація, яка створювала сприятливі умови для подальшого кооперування. Тобто готувала грунт для розвитку кооперації сільськогосподарської, що «відповідало й історичній послідовності в розвитку процесу кооперування: об'єднання селян як споживачів почалось раніше і розгорталось швидше. Цьому в значній мірі сприяв наступ на приватний капітал в торгівлі» $[31,211]$. Кооперація досить швидко розвивалась і значною мірою виконувала завдання 3 обслуговування господарських потреб села. На думку В. Данилова, «кооперація дала можливість селянину розвивати і зміцнювати своє господарство, покращуючи рівень його добробуту» [31, 238]. Аналізуючи перехід від «кооперування товарообігу до кооперування виробництва», дослідник розкрив специфіку нівелювання кооперації як самоврядної господарської організації на селі шляхом контрактації виробничих процесів. Він також спеціально підкреслив унікальну роль контрактації, яка «поставила сільськогосподарську кооперацію в таке положення, при якому значна частина виробничої, агрикультурної і організаційної діяльності кооперації будувалась і проводилась в основному через контрактацію і в безпосередньому зв'язку з нею» [31, 258]. Таким чином, В. Данилов підсумував, що «система контрактації в умовах Радянської держави була щаблем на шляху від дрібного селянського господарства до крупного соціалістичного» $[31,260]$.

У 1977 р. у ювілейному збірнику «Жовтень і радянське селянство, 1917 - 1927 рр.» була розміщена цікава аналітична стаття В. Дмитренка «Перехід до непу і розвиток кооперативної політики радянської держави» [32]. В ній він доволі об' єктивно як на той час розглянув особливості розвитку кооперативної політики радянської держави при переході до непу, лише дещо надмірно акцентуючи увагу на теоретичних дискусіях та аналізі статей і виступів В. Леніна у 1921 - 1923 рp. [33].

Загалом на кінець 1970-х рр. радянські історики створили цілісну концепцію кооперативного будівництва на селі. Не змінюючи методологію, вони, тим не менш, виокремили багато ключових моментів та факторів, які впливали на розвиток продуктивних сил українського села. Однак праці радянських істориків стосовно висвітлення кооперативної політики, кооперативного життя зводилися до обгрунтування правильності партійного курсу щодо форм і напрямів ії життєдіяльності. Будь-яке відхилення від усталеної доктрини в оцінках тих чи інших аспектів непу, зокрема такого ключового, як сільськогосподарська кооперація, трактувалося як неправильне, хибне. Марксистсько-ленінська апологетика залишалася домінантною методологічною базою радянських істориків.

У 1980-х рр. у дослідників знову з'являється інтерес до сільськогосподарської кооперації [34]. Різні аспекти діяльності сільськогосподарської кооперації в умовах непу на початку 1980-х рр. інтенсивно студіював А. Морозов. Він об'єктивно підійшов до висвітлення господарської роботи кооперації як передумови глибоких соціально-економічних перетворень в українському доколгоспному селі [35]. У подальшому основну свою увагу він приділив вивченню діяльності державно-кооперативної системи сільськогосподарського кредиту, їі ролі в піднесенні продуктивних сил села [36].

Ленінський кооперативний план та значення кооперації в соціалістичних перетвореннях на селі детально проаналізовано у двотомнику «Від капіталізму до соціалізму. Основні проблеми історії перехідного періоду в СРСР». Так, В. Дмитренко у п’ятому розділі першого тому відзначив, що швидкі темпи розвитку кооперативної мережі на селі сприяли утвердженню соціалістичного змісту сільськогосподарського механізму [37]. У третьому розділі другого тому М. Іваницький показав, що зростання загальної мережі й чисельності членів сільськогосподарських кооперативів ще до початку суцільної колективізації через різні форми кооперації охопило більше половини селянських господарств. Чверть від загальної кількості господарств пройшла крізь так звані виробничі форми кооперації, що полегшувало їм перехід до усуспільнення [38].

До проблем розвитку продуктивності сільського господарства України доби непу в контексті залучення селянських господарств до сільськогосподарської кооперації в середині 1980-х років активно звертались Л. Файн [39], А. Морозов [40]. У 1986 рр. вийшов 
друком збірник статей «Економічна політика радянської держави в перехідний період від капіталізму до соціалізму» [41], де проведено аналіз поглядів В. Леніна на нову економічну політику. Розглянуто принципи і методи регулювання багатоукладної економіки, політика допущення в сільське господарство приватного капіталу, методи його обмеження і витіснення. Приділено увагу показу відновлення та розвитку кооперації на селі. Л. Файн у статті «Кооперативна політика Радянської держави» розглянув різні етапи діяльності сільськогосподарської кооперації. В кінцевому разі, - підсумував він, - «в конкретних умовах переходу до суцільної колективізації, не була в повній мірі, до кінця використана вся сукупність форм сільськогосподарської кооперації, яка всім своїм розвитком до кінця 20 -х років була прилаштована до завдань виробничого кооперування і зіграла неабияку роль в його здійсненні» $[39,105]$. Це твердження підтримав i В. Данилов. Він неодноразово підкреслював, що кооперація в 1920-ті рр. являла собою своєрідну перехідну форму від капіталізму до соціалізму [41, 144].

У контексті нашого дослідження відзначимо збірник публікацій В. Данилова, В. Дмитренка, В. Лельчука «Неп і його доля» [42]. В ньому, зокрема, наводилась думка (В. Данилов), що в 1920-х pp. склалася міцна кооперативна система, яка «гарантувала кооперування основної маси селянських господарств, пришвидшення їх виробничого підйому, а тим самим - і загального економічного зростання країни» [42, 132]. «Трактування кооперування селянських господарств і подолання соціального розшарування села не як самостійних завдань соціалістичної перебудови суспільства, які мають свою внутрішню логіку і свої критерії успіху чи неуспіху, - відмічає дослідник, - а як засобів вирішення інших завдань була принциповим порушенням основних принципів ленінської концепції будівництва соціалізму, прямою відмовою від ленінського кооперативного плану» [42, 134].

Натомість кооперація, на переконання I. Козлова, який досліджував перспективи дрібнотоварного виробництва в сільському господарстві в роки непу, стала важливою перш за все для економічного стримування приватника $[43,61]$.

У 1990-му році вийшов етапний збірник аналітичних оглядів АН СРСР «Господарський механізм періоду нової економічної політики (за матеріалами 20-х років)» [44]. У ньому була розміщена й цікава стаття С. Цакунова «Кооперація в роки непу», в якій науковець проаналізував розвиток споживчої, промислової та сільськогосподарської кооперації 1920-х рр. Він дійшов висновку, що великою проблемою розвитку останньої була відсутність достатньої кількості обігових коштів, адже «одним із найбільш дієвих засобів розвитку продуктивних сил сільського господарства і проведення політики, спрямованої на поступовий підйом бідняцьких і середняцьких господарств, на думку переважної більшості вчених, був дрібний сільськогосподарський кредит». I лише господарський підйом 1923 - 1924 pp. «стабілізував фінансове положення» кооперації. Крім того, «створені економічні та правові умови дозволили в 1926 - 1928 рр., - на переконання С. Цакунова, - розгорнути заготівельну i постачальницьку діяльність сільськогосподарської кооперації на основі широкого використання генеральних договорів і угод». Тому вже у $1927-$ 1928 рр. «були укладені генеральні договори сільськогосподарської кооперації з текстильним синдикатом, Махорсиндикатом, Табаксировиною, Головхлопком, Цукротрестом, Шкірсиндикатом, акціонерним товариством «Вовна», Масложирсиндикатом та ін.» [45]. Загалом науковець охарактеризував діяльність сільськогосподарської кооперації позитивно.

Деякі аспекти господарської діяльності сільськогосподарської кооперації в роки нової економічної політики були розглянуті М. Тєпцовим у публікації «Аграрна політика: на крутих поворотах 20-30-х років» [46]. Дослідник відзначив важливе значення кооперації для відновлення і розвитку продуктивних сил на селі. У цьому контексті він спеціально підкреслив значення орендних відносин, коли селянин, чи кооперативне товариство орендували землю, обробляли їі, що давало можливість, 3 одного боку, інтенсифікувати виробництво, а з іншого - виробити більше продукції $[46,11]$. М. Тєпцов наголосив також на важливій ролі виробничої контрактації, суть якої зводилась до того, що «кооперативні органи ... брали зобов'язання по постачанню селянських господарств сортовим насінням, машинами, промисловими товарами, наданню агротехнічних і ветеринарних послуг ... селяни, в свою чергу, повинні були засіяти певну площу і здати (продати) вироблену продукцію в установлені терміни, із заздалегідь обумовленими кондиціями і цінами» $[46,13]$. Дослідник спеціально зазначив, що саме такі форми й напрями роботи $\mathrm{i}$ забезпечили в кінцевому разі швидкі темпи відновлення в сільському господарстві, які досягали в середньому $10 \%$ в рік у відбудовчий період $[46,14]$.

Отже, історіографія розвитку продуктивних сил у сільському господарстві України в контексті діяльності сільськогосподарської кооперації доволі різноманітна, хоча, за винятком невеликого часового проміжку часів «перебудови», і політично заангажована. На жаль, радянські дослідники, на відміну від зарубіжних науковців, досить мало уваги звертали на кооперацію в українському селі як цілісний господарський та соціальний організм, висуваючи на перший план лише окрему іiі іпостась - так звані виробничі форми кооперації. Історіографією 1920-х - початку 1950-х рр. проблеми сільськогосподарської кооперації взагалі замовчувалися. Лише починаючи з другої половини 1950-х рр., особливо після ряду публікацій В. Данилова, інтерес науковців до сільськогосподарської кооперації пожвавився. Однак праці радянських дослідників продовжували перебувати під тиском ідеологічної заданості, домінування принципу партійності, ніяк не виходили за межі марксистського трактування історії.

Однак доробок радянських дослідників заслуговує на увагу сучасних істориків, адже у їх працях був використаний значний фактичний матеріал, зокрема архівні документи, статистичні дані. Перед сучасними українськими дослідниками стоїть важливе завдання належного використання надбань попередніх історіографічних періодів, але вже з застосуванням сучасної парадигми історії. 
Висновки. Отже, у результаті проведеного нами історіографічного аналізу встановлено, що науковий доробок другої половини 1950-х - початку 1990-х рр. залишається важливою частиною історіографічного процесу висвітлення розвитку української сільськогосподарської кооперації у 1921 - 1929 рр. Радянська історична школа накопичила значний фактичний та фактологічний матеріал, у науковий обіг було введено чисельні архівні документи, статистичні дані, які на новій методологічній основі можуть використовуватися і сучасними науковцями. Відчутним недоліком радянської історіографії другої половини 1950-х - початку 1990-х рр. було те, що дослідники обходили залишки поза увагою реальне значення сільськогосподарської кооперації у виробничих процесах, її вплив на розвиток продуктивних сил індивідуальних селянських господарств доби непу, суспільно-громадську вагу в житті українського села. Радянські дослідники, на відміну від зарубіжних науковців, загалом мало уваги звертали на кооперацію в українському селі як на цілісний господарський та соціальний організм, висуваючи на перший план лише так звані виробничі форми кооперації. Історіографія 1920-х - початку 1950х pр. проблеми сільськогосподарської кооперації взагалі замовчувала. Лише з другої половини 1950-х pp., особливо після ряду публікацій В. Данилова, інтерес науковців до сільськогосподарської кооперації пожвавився. Проте кардинально ситуація змінилася лише за часів «перебудови».

У працях зарубіжних істориків кооперація стала предметом інтенсивних досліджень. Сільськогосподарська кооперація 1920-х рр. розцінювалася як головний засіб підйому продуктивних сил села, покращення положення селян, розгортання товарообігу в країні і зростання на цій основі внутрішнього ринку. Не менш активно зарубіжна історіографія розробляла питання «ленінського кооперативного плану».

\section{Список використаної літератури та джерел:}

1. Кульчицький С. В. Теоретичні аспекти нової економічної політики / С. В. Кульчицький // Сутність і особливості нової економічної політики в українському селі (1921-1928 рр.). - К. : Ін-т історії України НАНУ, 2000. C. 3-15; Марочко В. I. Українська селянська кооперація : історико-теоретичний аспект (1861-1929 рр.) / B. I. Марочко. - K. : M.P. Kots Publishing, 1995. - 224 c.; Морозов А. Г. Село і гроші. Українська кредитна кооперація в добу непу / А. Г. Морозов. - Черкаси : НДІТЕХІМ, 1993. - 274 с.; Оніпко Т. В. Виробничі галузі споживчої кооперації України в контексті нової економічної політики (1921-1928 рр.) : монографія / Т. В. Оніпко. Полтава : РВВ ПУЕТ, 2010.-363 с.; Биченко С. М. Внесок сільськогосподарської кооперації у зміцнення добробуту селянства України (1921-1929 рр.) : автореф. дис. ... канд. іст. наук : 07.00 .01 / С. М. Биченко; Черкас. нац. ун-т ім. Б. Хмельницького. - Черкаси, 2010 - 20 с.; Лазуренко В. М. Українське фермерство : злет і падіння (1921-1929 рр.). / В. М. Лазуренко. - Черкаси : ЧДТУ, 2013. - 474 с.; Кивгила I. Г Внесок економістів-аграрників у розбудову сільського господарства УСРР (19211929 рр.) : історіографія : дис. ... канд. іст. наук. ; спец. 07.00.06 - історіографія, джерелознавство та спеціальні історичні дисципліни / І. Г Кивгила; ДВНЗ «ПереяславХмельницький держ. пед. ун-т ім. Григорія Сковороди». Переяслав-Хмельницький, 2017. - 183 с.; Тренкін Ю. В. Фінансова діяльність сільськогосподарської кооперації Української СРР в умовах соціально-економічних трансформацій (1921-1929 рр.) : дис. канд. іст. наук ; спец. 07.00.01 - історія України / Ю. В. Тренкін; ДВНЗ «Переяслав-Хмельницький держ. пед. ун-т ім. Григорія Сковороди». - Переяслав-Хмельницький, 2019. - 244 с.

2. Владимирский М. Ф. О колхозной кооперации / М. Ф. Владимирский // На фронте коллективизации. - М., 1929. - № 1 (15 ноября). - С. 7-14.

3. Под знаменем партии Ленина-Сталина // Пропагандист и агитатор РККА. - 1939. - № 20. - С. 1-10.

4. Немаков Н. И. Ленинский кооперативный план - план социалистической переделки сельского хозяйства / Н. И. Немаков // Вестник МГУ. Серия : Общественные науки. - 1951. - Вып. 1, т. 1. -С. 3-17.

5. Абрамов Б. Партия большевиков - организатор борьбы на ликвидацию кулачества как класса / Б. Абрамов. - М. : Госполитиздат, 1952. - 135 с. ; Смирнов М. С. Борьба партии Ленина-Сталина за подготовку массового колхозного движения / М. С. Смирнов. - М. : Госполитиздат, $1952 .-147 \mathrm{c}$.

6. Бабій О. О. Сільськогосподарська кооперація України - одна $з$ передумов масової колективізації сільського господарства / О. О. Бабій // Питання економіки сільського господарства Української РСР : респ. міжвід. наук. зб. К., 1959. - Вип. 2. - С. 28-41; Шульга 3. П. Підготовка суцільної колективізації на Україні / 3. П. Шульга. - К. : Вид-во Київ. ун-ту, 1960. -151 с.

7. Билимович А. Д. Кооперация в России до, во время и после большевиков / А. Д. Билимович. - Франкфурт на Майне : Посев, 1955. - 129 с.

8. Билимович А. Д. Кооперация России до, во время и после большевиков / А. Д. Билимович; Ин-т экономики РАН. - М. : Наука, 2005. - 191 с.

9. Билимович А. Д. Экономический строй освобожденной России / А. Д. Билимович. - М. : Наука, 2006. - С. 87-168. 10. Гетьман-Кравченко М. О. Боротьба Комуністичної партії за створення сільськогосподарської кооперації на Україні і розгортання ії діяльності в 1921-1924 рр. / М. О. Гетьман-Кравченко // Наукові записки Луцького педінституту. - Луцьк, 1956. - Т. V, вип. 3. - С. 3-20 ; Бабій О. О. Сільськогосподарська кооперація України одна 3 передумов масової колективізації сільського господарства / О. О. Бабій // Питання економіки сільського господарства Української РСР : респ. міжвід. наук. зб. Київ, 1959. - Вип. 2. - С. 28-41; Денисовець П. М. Диференціація селянства України в умовах непу та її вплив на виробниче кооперування села (1921-1929 рр.) / П. М. Денисовець // Український історичний журнал. 1968. - № 1. - С. 57-67 ; Чмыга А. Ф. Очерки по истории колхозного движения на Украине (1921-1925) / А. Ф. Чмыга - М. : Изд-во. Моск. ун-та, 1959. - 224 с.

11. Гетьман-Кравченко Н. А. Деятельность Коммунистической партии Советского Союза по развитию и укреплению сельскохозяйственной кооперации (19211929 гг.) : по материалам Украины : автореф. дисс. ... канд. ист. наук / Н. А. Гетьман-Кравченко / Киев. гос. ун-т им. Т. Г. Шевченко. - Киев, 1959. - 24 с.

12. Бакуменко П. И. Укрепление союза рабочего класса и трудящегося крестьянства Украины в восстановительный период (1921-1925 гг.) : автореф. дисс. ... д-ра ист. наук / П. И. Бакуменко / АН УССР. Отд. экономики, истории, философии и права. - К., 1965. - 53 с.

13. Слинько И. И. Победа колхозного строя на Украине (1927-1932 гг.) : автореф. дисс. ... канд. ист. наук / И. И. Слинько. - К. : АН УССР, Ин-т истории, 1968. - 62 с. 14. Шульга 3. П. Підготовка суцільної колективізації на Україні / З. П. Шульга. - К. : Вид-во Київ. ун-ту, 1960. 151 с. ; Данилов В. П. Социально-экономические отношения в советской деревне накануне коллективизации / В. П. Данилов // Исторические записки / отв. ред. А. Л. Сидоров. - М. : Изд-во АН СССР, 1956. - Т. 55. С. 89-138; Данилов В. П. О характере социальноэкономических отношений советского крестьянства до коллективизации сельского хозяйства / В. П. Данилов - М. : Ин-т истории АН СССР, 1961. - 60 с. 
15. Данилов В. П. Социально-экономические отношения в советской деревне накануне коллективизации / В. П. Данилов // Исторические записки / отв. ред. А. Л. Сидоров. - М. : Изд-во АН СССР. - 1956. - Т. 55. C. $89-138$.

16. Данилов В. П. О характере социально-экономических отношений советского крестьянства до коллективизации сельского хозяйства / В. П. Данилов. - М. : Ин-т истории AH CCCP, 1961. - 60 c.

17. Громенко И. Е. Руководство Коммунистической партии Украины развертыванием производственного кооперирования на селе (1921-1925 гг.) : дисс. ... канд. ист. наук / И. Е. Громенко. - К., 1951. - 278 с. ; Терещенко М. В. Борьба Коммунистической партии за осуществление ленинского кооперативного плана в 1923-1925 гг. (по материалам Украины) : дисс. ... канд. ист. наук / М. В. Терещенко. - К., 1964.

18. Селунская В. М. Борьба Коммунистической партии Советского Союза за социалистическое преобразование сельского хозяйства. (окт. 1917-1934 гг.) : курс лекций, прочит. на ист. фак. МГУ ; В. М. Селунская. - М. : Высш. школа, 1961.-205 с. ; Трапезников С. П. Социалистическая кооперация - ленинский путь крестьян к коммунизму / С. П. Трапезников // Вопросы истории КПСС. - 1962. № 1.- С. 44-62 ; Данилов В. П. Ленинский кооперативный план и его осуществление в СССР / В. П. Данилов, Н. А. Ивницкий // Очерки истории коллективизации сельского хозяйства в союзных республиках. - М., 1963. C. 3-68.

19. Бланк Г. Я. Основы теории кооперации и очерк истории потребительской кооперации СССР. - Г. Я. Бланк. - М. : б. и., 1960. - Вып. 1 - 89 с. ; Булатов И. Г. Кооперация и ее роль в подготовке сплошной коллективизации И. Г. Булатов. - М. : Соцэкгиз, 1960.-200 с. ; Голиков В. А Важнейший этап развития сельскохозяйственной кооперации в СССР (1921-1929 гг.) / В. А. Голиков. - М. Сельхозиздат, 1963. - 200 с. ; Косой А. И. О природе и роли кооперации в переходной период от капитализма к коммунизму / А. И. Косой // Вопросы экономики. - М., 1963. - № 2. - С. 82-92.

20. Голиков В. А. Важнейший этап развития сельскохозяйственной кооперации в СССР (1921-1929 гг.) / В. А. Голиков. - М. : Сельхозиздат, 1963. - 200 с. 21. Витанович I. Історія українського кооперативного руху : із праць історично-філософічної секції НТШ / І. Витанович. - Нью Йорк : Т-во укр. кооперації, 1964 (Друк. полігр. вид. ТУК) . - 624 с.

22. Громенко I. Є. До питання про сільськогосподарську кооперацію в УРСР (1921-1925 рр.) / I. Є. Громенко // Український історичний журнал. - 1964. - № 5, (№ 44). C. $102-104$

23. Морозов Л. Ф. От кооперации буржуазной к кооперации социалистической : из истории становления советской кооперации / Л. Ф. Морозов. - М. : Мысль, 1969. -240 c.

24. Файн Л. Е. История разработки В. И. Лениным кооперативного плана / Л. Е. Файн. - М. : Мысль, 1970. 332 с. ; Файн Л. Е. Социально-экономическая характеристика кооперации в начальный период нэпа (19211923 гг.) / Л. Е. Файн // История СССР. - М., 1968. - № 5. С. 14-35 ; Денисовець П. М. Диференціація селянства України в умовах непу та її вплив на виробниче кооперування села (1921-1929 рр.) / П. М. Денисовець // Український історичний журнал. - 1968. - № 1. - С. 5767 ; Денисовець П. М. Колгоспне будівництво на Україні в 1921-1925 рр. : історична література / П. М. Денисовець. - Х. : Вид-во ХГУ, 1969. - 154 с.

25. Дмитренко В. П. Торговая политика Советского государства после перехода к нэпу. 1921-1924 гг. В. П. Дмитренко. - М. : Наука, 1971. - 271 с.

26. Чмыга А. Ф. Колхозное движение на Украине (19171929 гг.) : очерки истории / А. Ф. Чмыга. - М. : Изд-во МГУ, 1974. - 320 с
27. Зеленин И. Е. Совхозы в первое десятилетие Советской власти (1917-1927 гг.) / И. Е. Зеленин. - М. : Наука, 1972 $392 \mathrm{c}$.

28. История социалистической экономики СССР : в 7 т. Т. 3. Создание фундамента социалистической экономики в СССР 1926-1932 гг. / [ред. колл. В. А. Виноградов, Ю. Ф. Воробьев, И. А. Гладков (отв. ред.) и др.]. - М. : Наука, 1977. - 535 с.

29. Дмитренко В. П. Партия и кооперация В. П. Дмитренко, Л. Ф. Морозов, В. И. Погудин. - М. : Политиздат, 1978. - 296 с.

30. Данилов В. П. Советская доколхозная деревня : население, землепользование, хозяйство / В. П. Данилов ; АН СССР. Ин-т истории СССР. - М. : Наука, 1977. - 318 с. 31. Данилов В. П. Советская доколхозная деревня : социальная структура, социальные отношения / В. П. Данилов. - М. : Наука, 1979. - 359 с.

32. Октябрь и советское крестьянство, 1917-1927 гг. / [ред. И. М. Волков]. - М. : Наука, 1977. - 295 с.

33. Дмитренко В. П. Переход к нэпу и развитие кооперативной политики советского государства / В. П. Дмитренко // Октябрь и советское крестьянство, 1917-1927 гг. / [ред. И. М. Волков]. - М. : Наука, 1977. - С. 192-218. 34. Дмитренко В. П. Советская экономическая политика в первые годы пролетарской диктатуры : проблемы регулирования рыночных отношений / В. П. Дмитренко ; отв. ред. Ю. А. Поляков. - М. : Наука, 1986. - 252 с. ; Морозов А. Г. Развитие кооперации и проблемы личных подсобных хозяйств / А. Г. Морозов // Социальнополитические науки. - 1988. - № 8. - С. 14-22.

35. Морозов А. Г. Сільськогосподарська кооперація як передумова соціально-економічних перетворень в доколгоспному селі / А. Г. Морозов ; Донецьк. у-т, 1983. Деп. в ІНІСН СРСР № 14377. - 36 с.

36. Морозов А. Г. Розвиток державно-кооперативної системи сільськогосподарського кредиту на Україні / А. Г. Морозов. - Донецьк. У-т, 1983. - Деп. в ІНІСН СРСР № $14357 .-48 \mathrm{c}$.

37. От капитализма к социализму. Основные проблемы истории переходного периода в СССР 1917-1937 гг. : в 2 т. T. 1. Победа социалистической революции. Начало переходного периода 1917-1927 гг. / АН СССР, Ин-т истории СССР ; ред. Ю. А. Поляков. - М. : Наука, 1981. $519 \mathrm{c}$.

38. От капитализма к социализму. Основные проблемы истории переходного периода в СССР 1917-1937 гг. : в 2 т. Т. 2. Развернутое строительство социализма в СССР 1928-1937 гг. / АН СССР, Ин-т истории СССР ; под общ. ред. Ю. А. Полякова. - М. : Наука, 1981. - 440 с.

39. Файн Л. Е. Кооперативная политика Советского государства / Л. Е. Файн // Экономическая политика Советского государства в переходный период от капитализма к социализму. - М. : Наука, 1986. - С. 96-115. 40. Морозов А. Г. Діяльність сільськогосподарської кооперації УСРР по зміцненню колгоспів (1921-1929рр.)

/ А. Г. Морозов // Український історичний журнал. - 1984. - № 2. - С. 74-82.

41. Экономическая политика советского государства в переходный период от капитализма к социализму: сб. ст. / АН СССР, Ин-т истории СССР ; отв. ред. М. П. Ким. М. : Наука, 1986. -255 с.

42. Данилов В. П. Нэп и его судьба / В. П. Данилов, В. П. Дмитренко, В. С. Лельчук // Историки спорят : 13 бесед. - М., 1988. - С. 122-190.

43. Козлов И. А. Революция, НЭП и судьбы мелкого производства / И. А. Козлов // Историческое значение НЭПа. : сб. науч. трудов. - М. : Ин-т истории СССР, 1990. - C. 61-89.

44. Хозяйственный механизм периода новой экономической политики : по материалам 20-х годов : сб. обзоров / сост. и отв. ред. Е. В. Богомолова ; АН СССР. Ин-т науч. информации по обществ. наукам. - М., 1990. - 178 с. 45. Цакунов С. В. Кооперация в годы нэпа [Электронный 
peсурс] // Хозяйственный механизм периода новой экономической политики (по материалам 20-х годов) : сб. обзоров ; АН СССР, ИНИОН, 1990. - Режим доступа : http://closelook.narod.ru/coop_nep.html

46. Тепцов Н. В. Аграрная политика : на крутых поворотах 20-30-х годов / Н. В. Тепцов. - М. : Знание, 1990. $-64 \mathrm{c}$.

\section{References:}

1. Kulchytskyi, S. V. (2000). Theoretical aspects of the new economic policy. Sutnist i osoblyvosti novoi ekonomichnoi polityky v ukrainskomu seli (1921-1928) (The essence and features of the new economic policy in Ukrainian village (19211928). Kyiv: In-t istorii Ukrainy NANU (in Ukr.); Marochko, V. I. (1995). Ukrainian peasant cooperation: historical and theoretical aspect (1861-1929). Kyiv: M.R. Kots Publishing (in Ukr.); Morozov, A. H. (1993). The village and the money. Ukrainian credit cooperation in the days of the NEP. Cherkasy: NDITEKhIM (in Ukr.); Onipko, T. V. (2010). Manufacturing industries of consumer cooperatives of Ukraine in the contex of the new economic policy (1921-1928): monograph. Poltava: RVV PUET (in Ukr.); Bychenko, S. M. (2010). Contribution of agricultural cooperatives to the well-being of the peasantry of Ukraine (1921-1929): author's abstract for Ph.D. in History: specialty 07.00.01. Cherkasy nats. un-t named after B. Khmelnytskyy (in Ukr.); Lazurenko, V. M. (2013). Ukrainian farming: flight and fall (1921-1929). Cherkasy: ChDTU (in Ukr.); Kyvhyla, I. H. (2017). The contribution of economists-agrarians to the development of agriculture of the Ukrainian SSR (1921-1929): historiography: thesis for Ph.D. in History: specialty 07.00.06 - Historiography, Source Studies and Special Historical Disciplines. Pereyaslav-Khmelnytsky State Pedagogical University named after Gregory Skovoroda (in Ukr.); Trenkin, Yu. V. (2019). Financial activities of agricultural cooperatives of the Ukrainian SRP in the conditions of socio-economic transformations (1921-1929): thesis for Ph.D. in History: specialty 07.00.01 - History of Ukraine. Pereyaslav-Khmelnytsky State Pedagogical University named after Gregory Skovoroda (in Ukr.).

2. Vladimirskyi, M. F. (1929). About kolkhoz co-operation. $\mathrm{Na}$ fronte kollektivizatsiyi (At the front of collectivization). Moscow, No. 1 (November, 15), 7-14 (in Rus.).

3. Under the banner of Lenin-Stalin's party (1939). Propagandist $\mathrm{i}$ agitator RKKA (Propagandist and agitator of the Red Army), 20, 1-10 (in Rus.).

4. Nemakov, N. I. (1951). Lenin's cooperative plan - a plan for socialist redevelopment of agriculture. Vestnik MGU. Seriya: Obshchestvennyye. nauki (Bulletin of Moscow State University. Series: Common sciences, 1 (1), 3-17 (in Rus.). 5. Abramov, B. (1952). The Bolshevik Party - the organizer of the struggle to eliminate the kulaks as a class. Moscow: Gospolitizdat (in Rus.); Smirnov, M. S. (1952). The struggle of Lenin-Stalin's party for the preparation of the mass collective-farm movement. Moscow: Gospolitizdat (in Rus.) 6. Babii, O. O. (1959). Agricultural cooperation of Ukraine one of the prerequisites for mass collectivization of agriculture. Pytannia ekonomiky silskoho hospodarstva Ukrainskoi RSR (Issues of the economy of agriculture of the Ukrainian SSR) republ: sci. proceedings. Kyiv, 2, 28-41 (in Ukr.); Shulga, Z. P. (1960). Preparation of continuing collectivization in Ukraine. Kyiv: Vyd-vo Kyiv. un-tu (in Ukr.).

7. Bylymovych, A. D. (1955). Cooperatives in Russia before, during and after the Bolsheviks. Frankfurt na Maine: Posev (in Rus.).

8. Bylymovych, A. D. (2005). Cooperatives of Russia before, during and after the Bolsheviks; Institute of Economics of Russian Academy of Sciences Moscow: Nauka (in Rus.). 9. Bylymovych, A. D. (2006). Economic system of liberated Russia. Ekonomicheskyi stroi osvobozhdennoi Rossiyi (Economic system of liberated Russia); Institute of Economics of Russian Academy of Sciences. Moscow: Nauka (in Rus.). 10. Hetman-Kravchenko, M. O. (1956). The struggle of the Communist Party for the creation of agricultural cooperation in Ukraine and the deployment of its activities in 1921-1924. Naukovi zapysky Lutskoho pedinstytutu (Scientific Notes of the Lutsk Pedagogical Institute), Lutsk, V (3), 3-20 (in Ukr.); Babii, O. O. (1959). Agricultural cooperatives of Ukraine one of the prerequisites for mass collectivization of agriculture. / Pytannia ekonomiky silskoho hospodarstva Ukrainskoi RSR (Issues of the economy of agriculture of the Ukrainian SSR): republ: sci. proceedings. Kyiv, 2, 28-41 (in Ukr.); Denysovets, P. M. (1968). Differentiation of the peasantry of Ukraine in the conditions of the NEP and its influence on the production cooperatives of the village (1921-1929). Ukrainskyi istorychnyi zhurnal (Ukrainian Historical Journal), 1, 57-67 (in Ukr.); Chmyga, A. F. (1959). Essays on the history of the collective-farm movement in Ukraine (1921-1925). Moscow: Izd-vo Mosk. un-ta (in Rus.).

11. Hetman-Kravchenko, N. A. (1959). Activities of the Communist party of the Soviet Union for the development and strengthening of agricultural cooperatives (1921-1929): on materials of Ukraine: author's abstract for Ph.D. in History; Kiev. gos. un-t im. T. G. Shevchenko (in Rus.).

12. Bakumenko, P. I. (1965). Strengthening the alliance of the working class and the working peasants of Ukraine in the reconstruction period (1921-1925): author's abstract for Dr.Sc. in History. Academy of Sciences of the Ukrainian SSR. Branch of Economics, History, Philosophy and Law. Kiev (in Rus.). 13. Slinko, I. I. (1968). The victory of the collective-farm system in Ukraine (1927-1932): author's abstract for Ph.D. in History. Kiev: AN USSR. In-t istoriyi (in Rus.).

14. Shulha, Z. P. (1960). Preparation of continuous collectivization in Ukraine. Kyiv: Vyd-vo Kyiv. un-tu (in Ukr.); Danilov, V. P. (1956). Socio-economic relations in the Soviet village on the eve of collectivization. Istoricheskiye zapiski (Historical notes). In A. L. Sidorov (Ed.). Moscow: Izd-vo AN SSSR, 55, 89-138 (in Rus.); Danilov, V. P. (1961). The nature of socio-economic relations of the Soviet peasantry before the collectivization of agriculture. Moscow: In-t istoriyi AN SSSR (in Rus.).

15. Danilov, V. P. (1956). Socio-economic relations in the Soviet village on the eve of collectivization. Istoricheskiye zapiski (Historical notes). In A. L. Sidorov (Ed.). Moscow: Izd-vo AN SSSR, 55, 89-138 (in Rus.).

16. Danilov, V. P. (1961). The nature of socio-economic relations of the Soviet peasantry before the collectivization of agriculture. Moscow: In-t istoriyi AN SSSR (in Rus.).

17. Gromenko, I. Ye. (1951). The leadership of the Communist Party of Ukraine by the deployment of production cooperatives in the countryside (1921-1925): author's abstract for Ph.D. in History. Kiev (in Rus.); Tereshchenko, M. V. (1964). The struggle of the Communist Party for the implementation of Leninist cooperative plan in 1923-1925. (on the materials of Ukraine): author's abstract for Ph.D. in History. Kiev (in Rus.).

18. Selunskaia, V. M. (1961). The struggle of the Communist Party of the Soviet Union for the socialist transformation of agriculture (Oct. 1917-1934): a course of lectures, read at the MSU History faculty. Moscow: Vyssh. shkola (in Rus.); Trapeznikov, S. P. (1962). Socialist cooperation - Leninist path of peasants to communism. Voprosy istoriyi KPSS (Questions of the history of the Communist Party), 1, 44-62 (in Rus.); Danilov, V. P., \& Ivnitsky, N. A. (1963). Lenin's cooperative plan and its implementation in the USSR. Ocherki istoriyi kollektivizatsiyi selskogo khoziaistva $\mathrm{v}$ soiuznykh respublikakh (Essays on the history of collectivization of agriculture in the Union republics). Moscow (in Rus.).

19. Blank, G. Ya. (1960). Fundamentals of the theory of cooperation and the essay on the history of the consumer cooperatives of the USSR. Moscow, 1 (in Rus.); Bulatov, I. G. (1960). Cooperatives and their role in the preparation of continuous collectivization. Moscow: Sotsekgiz (in Rus.); Golikov, V. A. (1963). The most important stage in the development of agricultural co-operation in the USSR (19211929). Moscow: Selkhozizdat (in Rus.); Kosoi, A. I. (1963). On the nature and role of cooperatives in the transitional period 
from capitalism to communism. Voprosy ekonomiki (Issues of Economics). Moscow, 2, 82-92 (in Rus.).

20. Golikov, V. A. (1963). The most important stage in the development of agricultural co-operation in the USSR (19211929). Moscow: Selkhozyzdat (in Rus.).

21. Vytanovych, I. (1964). The history of the Ukrainian cooperative movement: from the works of historicalphilosophical section of the NTSh. New York: T-vo Ukr. kooperatsii (in Ukr.).

22. Hromenko, I. Ye. (1964). On the issue of agricultural cooperatives in the Ukrainian SSR (1921-1925). Ukrainskyi istorychnyi zhurnal (Ukrainian Historical Journal), 5 (44), 102104 (in Ukr.)

23. Morozov, L. F. (1969). From bourgeois cooperatives to socialist co-operatives: from the history of the Soviet cooperatives formation. Moscow: Mysl (in Rus.).

24. Fain, L. Ye. (1970). The history of V. I. Lenin's development of the cooperative plan. Moscow: Mysl (in Rus.); Fain, L. Ye. Socio-economic characteristics of cooperatives in the initial period of the NEP (1921-1923). Istoriya SSSR (History of the USSR), Moscow, 5, 14-35 (in Rus.); Denysovets, P. M. (1968). Differentiation of the peasantry of Ukraine in the conditions of the NEP and its influence on the production cooperatives of the village (1921-1929). Ukrainskyi istorychnyi zhurnal (Ukrainian Historical Journal), 1, 57-67 (in Ukr.); Denysovets, P. M. (1969). Collective farm building in Ukraine in 1921-1925: historical literature. Kharkiv: Vydvo KhHU (in Ukr.).

25. Dmitrenko, V. P. (1971). The trade policy of the Soviet state after the transition to NEP. 1921-1924. Moscow: Nauka (in Rus.).

26. Chmyga, A. F. (1974). The Collective farm movement in Ukraine (1917-1929): essays on history. Moscow: Izd-vo MGU (in Rus.).

27. Zelenin, I. Ye. Sovkhozes in the first decade of Soviet power (1917-1927). Moscow: Nauka (in Rus.).

28. The history of the socialist economy of the USSR (1977): in 7 vol. Vol. 3. Creation of the foundation of the socialist economy in the USSR 1926-1932. In V. A. Vinogradov, Yu. F. Vorobiev, I. A. Gladkov et al. (Eds.). Moscow: Nauka (in Rus.). 29. Dmitrenko, V. P., Morozov, L. F., \& Pogudin, V. I. (1978). Party and cooperatives. Moscow: Politizdat (in Rus.).

30. Danilov, V. P. (1977). Soviet pre-kolkhoz village: population, land tenure, economy. Academy of Sciences of the USSR. Institute of History of the USSR. Moscow: Nauka (in Rus.).

31. Danilov, V. P. (1979). Soviet pre-kolkhoz village: social structure, social relations. Moscow: Nauka (in Rus.).

32. October and the Soviet peasantry, 1917-1927 (1977). In I. M. Volkov (Ed.). Moscow: Nauka (in Rus.).

33. Dmitrenko, V. P. (1977). The transition to the NEP and the development of cooperative policy of the Soviet state. Oktiabr i sovetskoe krestianstvo, 1917-1927 (October and the Soviet peasantry, 1917-1927). In I. M. Volkov (Ed.). Moscow: Nauka (in Rus.).

34. Dmitrenko, V. P. (1986). Soviet economic policy in the early years of the proletarian dictatorship: problems of regulating market relations. In Yu. A. Poliakov (Ed.). Moscow: Nauka (in Rus.); Morozov, A. G. (1988). Development of cooperatives and the problems of personal subsidiary farms Sotsialno-politicheskiye nauki (Social and political sciences), 8, 14-22 (in Rus.).

35. Morozov, A. H. (1983). Agricultural cooperatives as a precondition for socio-economic transformations in the prefarm village. Donetsk. un-t: Dep. in INISN SRSR No. 14377 (in Ukr.).

36. Morozov, A. H. (1983). Development of the statecooperative system of agricultural credit in Ukraine. Donetsk un-t. Dep. in INISN USSR No. 14357 (in Ukr.).

37. From capitalism to socialism. The main problems of the history of the transition period in the USSR in 1917-1937 (1981): in 2 vol. Vol. 1. The victory of the socialist revolution. The beginning of the transition period 1917-1927. / USSR
Academy of Sciences, Institute of History of the USSR. In Yu. A. Poliakov (Ed.). Moscow: Nauka (in Rus.)

38. From capitalism to socialism. The main problems of the history of the transition period in the USSR in 1917-1937 (1981): in 2 vol. Vol. 2. The extensive construction of socialism in the USSR in 1928-1937. / USSR Academy of Sciences, Institute of History of the USSR. In Yu. A. Poliakov (Ed.). Moscow: Nauka (in Rus.).

39. Fain, L. Ye. (1986). Cooperative policy of the Soviet State // Ekonomicheskaia politika Sovetskogo gosudarstva v perekhodnyi period ot kapitalizma k sotsializmu (The Economic policy of the Soviet State in the transition period from capitalism to socialism. Moscow: Nauka (in Rus.).

40. Morozov, A. H. (1984). Activities of agricultural cooperatives of the Ukrainian SSR on the strengthening of collective farms (1921-1929) // Ukrainskyi istorychnyi zhurnal (Ukrainian Historical Journal), 2, 74-82 (in Ukr.).

41. Economic policy of the Soviet state during the transition from capitalism to socialism: coll. of papers (1986). USSR Academy of Sciences, Institute of History of the USSR. In M. P. Kim (Ed.). Moscow: Nauka (in Rus.).

42. Danilov, V. P., Dmitrenko, V. P., \& Lelchuk, V. S. (1988). NEP and its fate. // Istoriki sporiat: 13 besed (Historians argue: 13 conversations). Moscow (in Russ.).

43. Kozlov, I. A. (1990). Revolution, NEP and the fates of small production // Istoricheskoe znacheniye NEPa (Historical significance of NEP): coll. of sci. papers. Moscow: In-t istoriyi SSSR (in Rus.).

44. Economic mechanism of the period of the new economic policy: on the materials of the 20-ies (1990): coll. of reviews. In E. V. Bogomolov. USSR Academy of Sciences. Institute of scientific information on social sciences. Moscow (in Rus.). 45. Tsakunov, S. V. Cooperation in the years of the NEP. Khoziaistvennyi mekhanizm perioda novoi ekonomicheskoi politiki (po materialam 20-kh godov) (Economic mechanism of the period of the new economic policy (on the materials of the 20's)) (1990): coll. of reviews; AN USSR, INION. Retrieved from http://closelook.narod.ru/coop_nep.html

46. Teptsov, N. V. (1990). Agrarian policy: on the steep turns of the 20-30's. Moscow: Znaniye (in Rus.).

Yu. Lazurenko

\section{PECULIARITIES OF COVERAGE OF AGRICULTURAL COOPERATIVES ACTIVITIES OF THE NEP ERA IN THE HISTORIOGRAPHY OF THE LATE 50'S - EARLY 90'S OF THE XX CENTURY}

Introduction. Further development of Ukraine as a modern, socially oriented European state requires the modernization of agrarian sector of the economy. Its successful reformation is impossible without taking into account previous historical experience. The majority of both domestic and foreign researchers agree that industrial, economic and therefore social development of Ukrainian village of the 1920's was progressive, and the period of the new economic policy had many common features with modern economic model. In this regard, a special analysis of the national historical experience of functioning of agriculture in Ukraine in the NEP era is quite reasonable, especially since the attention of Ukrainian society to further ways of establishing the effective functioning of agrarian sector of the national economy remains extremely high.

Purpose. Coverage of the development of productive forces in the agriculture of Ukraine in the context of agricultural cooperatives' activities of the period of the 
new economic policy in the historiography of the late 50 's - early 90's of the XX century.

Methods. The paper is based on comparative and problem-thematic analysis of the historiography source base, which has made it possible to determine internal laws and the dialectics of their development in the light of quantitative and qualitative changes. The author has used comparative-historical, problem-chronological, retrospective, historical-situational, logical-analytical methods and methods of analysis and synthesis, grouping and typology.

Results. It is established that Soviet researchers, in contrast to foreign scientists, generally have paid little attention to cooperatives in Ukrainian village as a holistic economic and social organism, placing only the so-called industrial forms of cooperatives on the foreground. The historiography of the 1920s - early 1950's generally kept silent about the problems of agricultural cooperatives. Only from the second half of the 1950's, especially after a number of publications by a scientist-agrarian $\mathrm{V}$. Danylov, the interest of scientists in agricultural cooperatives revived. However, the situation has changed radically only at the time of "perestroika".

It is established that in the works of foreign historians, cooperatives have become the subject of intensive research. Agricultural cooperatives of the 1920s have been regarded in them as the main means of raising the productive forces of the village, improving the position of the peasants, developing the country's trade turnover and the growth of domestic market on this basis. No less active foreign historiography have developed the issue of Lenin's cooperative plan.

Originality. The scientific novelty of the obtained results is determined by: the very formulation of the theme, which has not yet been the subject of a special scientific historiographical study; elucidation of general theoretical aspects and specific directions of the study of the development of agricultural cooperatives of the NEP era in scientific and historical works of the 50's 90's of the last century.

Conclusion Thus, as a result of our historiographical analysis, it has been established that scientific achievements of the second half of the 1950s - early 1990s remain an important part of historiographical process of covering the development of Ukrainian agricultural cooperatives in 1921-1929. The Soviet historical school has accumulated significant factual material, numerous archival documents, statistical data, which on the new methodological basis can be used by modern scholars, were entered into scientific circulation. A noticeable disadvantage of Soviet historiography of the late 1950s - early 1990s was that the researchers ignored the real significance of agricultural cooperatives in production processes, their influence on the development of productive forces of individual peasant farms of the NEP era, social and public importance in the life of Ukrainian villages.

Key words: researcher, historiography, scientist, NEP, works, peasantry, peasant farms, agriculture, agricultural cooperatives.
УДК 930.1(438):070(477.83)

DOI: $10.31651 / 2413-8142-2019-21-97-101$

Л. М. Лазурко

кандидат історичних наук, доиент кафедри історії України Дрогобицького державного педагогічного університету імені Івана Франка

\section{ЛЬВІВСЬКИЙ ЧАСОПИС «КWARTALNIK HISTORYCZNY» ЯК КОМУНІКАЦІЙНА ПЛАТФОРМА ДЛЯ ОБГОВОРЕННЯ ОРГАНІЗАЦІЙНИХ ТРАНСФОРМАЦІЙ ПОЛЬСЬКОЇ ІСТОРИЧНОЇ НАУКИ (1918 - 1939)}

У статті розкрито відображення становлення польської історичної науки міжвоєнного періоду на cmорінках часопису "Kwartalnik Historyczny». Представлено процес інституиіоналізації польської науки, пов'язаний з перетворенням Історичного товариства у Львові в організацію національного масштабу. Відзначено, що відкритість часопису «Kwartalnik Historyczny» для обговорення означеного ряду проблем сприяла їх вирішенню. Вивчення ичих прочесів дозволяє глибше пізнати як відбувалося становлення польської історичної науки після здобуття державної незалежності у 1918 р. та ї̈ подальшу організаційну еволюиію.

Ключові слова. Інституційний розвиток, історична наука, наукова преса, Польське історичне товариство, Львів, міжвоснне двадиятиліття.

Постановка проблеми. Здобуття Польщею незалежності та творення самостійної держави після закінчення Першої світової війни започаткували новий період у розвитку національної історичної науки, пов'язаний зі змінами їі функцій та модифікацією організаційного підгрунтя. Події війни загальмували звичний хід наукового життя, а потреба розвитку інфраструктури апарату державного управління, суспільних інституцій та дипломатична діяльність відвернули від професійних занять значну кількість науковців. Разом із тим по мірі врегулювання ситуації, відкривались нові можливості професійного зростання: новостворена держава взяла під свою матеріальну опіку історичну науку, створивши умови для ії̈ потужного розвитку. Як наслідок, спостерігаємо відкриття нових історичних кафедр в університетах, закладання бібліотек, організацію мережі архівів, що ставали осередками дослідницької та дидактичної діяльності. Такі якісні зміни в організаційній структурі історичної науки вимагали відповідного кадрового наповнення - виховання нової генерації істориків. Ці та інші проблеми становлення національної науки стали об“єктом уважного обговорення тогочасної інтелектуальної еліти, зосередженої довкола першого польського фахового історичного часопису «Kwartalnik Historyczny» (далі - КН), який видавався у Львові. Відтак актуальним є дослідження діяльності видання як комунікаційної платформи з обговорення організаційних трансформацій польської історичної науки міжвоєнного двадцятиліття. Це дозволить встановити як, попри зрозумілі централізаційні тенденції у новопосталій польській державі, головним осередком істориків Польщі залишився Львів, а не Варшава.

Аналіз останніх досліджень і публікацій. До питання функціонування часопису у контексті 